Marquette University

e-Publications@Marquette

College of Communication Faculty Research and

Publications

Communication, College of

$1-1-2006$

Reconsidering Public Relations' Infatuation with Dialogue: Why Engagement and Reconciliation Can Be More Ethical Than Symmetry and Reciprocity

Kevin L. Stoker

Brigham Young University

Kati Tusinski Berg

Marquette University, kati.berg@marquette.edu

Accepted version. Journal of Mass Media Ethics, Vol. 21, No. 2-3 (2006): 156-176. DOI. (C) 2006

Taylor \& Francis. Used with permission.

Kati Tusinski Berg was affiliated with University of Oregon at the time of publication.

The author of this document, Kati Tusinski Berg, published under the name Kati Tusinski at the time of publication. 


\title{
Reconsidering Public Relations' Infatuation with Dialogue: Why Engagement and Reconciliation Can Be More Ethical Than Symmetry and Reciprocity
}

\author{
Kevin L. Stoker \\ Department of Communications, \\ Brigham Young University \\ Provo, UT \\ Kati A. Tusinski \\ School of Journalism and Communication, \\ University of Oregon \\ Eugene, OR
}

\begin{abstract}
:
Advocates of dialogic communication have promoted two-way symmetrical communication as the most effective and ethical model for public relations. This article uses John Durham Peters's critique of dialogic communication to reconsider this infatuation with dialogue. In this article, we argue that dialogue's potential for selectivity and tyranny poses moral problems for public relations. Dialogue's emphasis on reciprocal communication also saddles public relations with ethically questionable quid permission has been granted for this version to appear in e-Publications@Marquette. Taylor \& Francis (Routledge) does not grant permission for this article to be further copied/distributed or hosted elsewhere without the express permission from Taylor \& Francis (Routledge).
\end{abstract}


pro quo relationships. We contend that dissemination can be more just than dialogue because it demands more integrity of the source and recognizes the freedom and individuality of the source. The type of communication, such as dialogue or dissemination, is less important than the mutual discovery of truth. Reconciliation, a new model of public relations, is proposed as an alternative to pure dialogue. Reconciliation recognizes and values individuality and differences, and integrity is no longer sacrificed at the altar of agreement.

\section{Communication: Both "Bridge and Chasm"}

When WellPoint, a California-based holding company, acquired Blue Cross and Blue Shield of Georgia, it soon learned that the two companies were as far apart culturally as they were geographically. The buyer's communications team discovered that Blue Cross had never undergone reorganization while WellPoint reorganized on a regular basis. "I didn't get the cultural issue until I was there," said Ken Ferber, WellPoint's vice president of communications. "I came back to my boss and said, 'We're not ready'" (Communicating Corporate Change, 2001, p. 1).

Typical public relations strategy called for Ferber to initiate a "two-way concept" of public relations that "emphasizes communication exchange, reciprocity, and mutual understanding" (Cutlip, Center, \& Broom, 2000, p. 4). Using two-way communication, Wellpoint and Blue Cross could adjust and adapt to each other until they reached a consensus or an agreement on a common culture. This approach is rooted in open systems theory and is best known in public relations literature as the two-way symmetrical model of public relations (Grunig \& Hunt, 1984). The two-way symmetrical model is considered the most ethical (Grunig, 1989; Pearson, 1989) because one-way "public relations relies almost entirely on propaganda and persuasive communication" (Cutlip et al., 2000, p. 3). However, how realistic is it for two companies with distinct corporate cultures to achieve a symmetrical relationship, especially when a big company acquires a smaller one? The merger's success may depend on the two companies recognizing their differences rather than seeking agreement on a common culture. Recognizing differences takes into consideration human nature, that people may associate with a particular company because its culture fits their personalities. As philosopher William James (1890/1952) said, each person may divide the universe into

Journal of Mass Media Ethics, Vol. 21, No. 2-3 (2006): pg. 156-176. DOI. This article is (c) Taylor \& Francis (Routledge) and permission has been granted for this version to appear in e-Publications@Marquette. Taylor \& Francis (Routledge) does not grant permission for this article to be further copied/distributed or hosted elsewhere without the express permission from Taylor \& Francis (Routledge). 
two separate halves and associate with one or the other but no matter which one a person chooses, each draws a dividing line in a different place:

The altogether unique kind of interest each human mind feels in those parts of creation which it can call me or mine may be a moral riddle, but it is a fundamental psychological fact. ... Each of us dichotomizes the Kosmos in a different place. (as cited Peters, 1999, p. 4)

Individual distinctions, let alone group differences, make the symmetry of dialogic communication an elusive goal. Although many communication theorists would like to believe that true communication means reaching agreement or achieving an understanding, the reality is that communication is both a "bridge and chasm," bringing people closer to agreement and exposing the disagreement lying in between (Peters, 1999, p. 5). Peters defined communication as the project of reconciling self and other. To think it might do more may be a recipe for failure.

Peters (1999) defended his contentions in his book Speaking Into the Air: A History of the Idea of Communication. Although Peters did not address public relations in his book, he did raise important questions about whether dialogue is always the best approach to communication. Indeed, Peters's work has the potential of liberating public relations from an unhealthy infatuation with dialogue and its antecedents, such as symmetrical and reciprocal communication. This is not to say that dialogue is always bad or that it can never be ethical. On the contrary, Peters saw dialogue as lofty goal for communication; he just worried that it "may blind us to the more subtle splendors of dissemination or suspended dialogue" (p. 62). There is value in nonreciprocal forms of communication.

In this article, we attempt to apply Peters's (1999) critique of dialogue to public relations. We question the basic assumptions of dialogic public relations by examining the philosophical roots of dialogue and two-way symmetric communication. This deconstruction of dialogue exposes moral cracks and contradictions in the concept and its application to public relations.

Journal of Mass Media Ethics, Vol. 21, No. 2-3 (2006): pg. 156-176. DOI. This article is (c) Taylor \& Francis (Routledge) and permission has been granted for this version to appear in e-Publications@Marquette. Taylor \& Francis (Routledge) does not grant permission for this article to be further copied/distributed or hosted elsewhere without the express permission from Taylor \& Francis (Routledge). 
Second, in this article we show how dialogue's emphasis on reciprocal communication saddles public relations with ethically questionable quid pro quo relationships. Third, a look at Peters's analysis of dissemination shows that contrary to dialogue, dissemination can enhance freedom, responsibility, diversity, and reconciliation. Finally, we introduce reconciliation as a new model of ethical public relations that recognizes the strengths and limitations of dialogue and dissemination.

\section{Dialogue in Public Relations}

In recent years, the business world has embraced dialogue as the role model for effective, ethical communication.

In certain quarters dialogue has attained something of a holy status. It is held up as the summit of human encounter, the essence of liberal education, and the medium of participatory democracy. By virtue of its reciprocity and interaction, dialogue is taken as superior to the one-way communiqués of mass media and mass culture. (Peters, 1999, p. 33)

Public relations research and theory is no exception to this rule.

If one accepts the conclusions of post-modern rhetorical theory-that communication processes play a fundamental role in the generation of both scientific and moral truth-then ethical business conduct is conduct that is sanctioned within the parameters of a dialogic communication process ... No other source of ethical standards exists. Conduct that is not sanctioned or legitimized by that process is open to attack on moral grounds. (Pearson, 1989, p. 127)

The argument that dialogue should become the central focus for business ethics has become a common theme for public relations scholars. In their groundbreaking work, Grunig and Hunt (1984) identified four models of public relations: press agentry or publicity, public information, two-way asymmetrical, and two-way symmetrical. Grunig (1989) praised two-way symmetrical as the most "excellent" of the models and labeled press agentry or publicity as "propagandistic public relations," public information as "journalists-in-residence" 
dissemination absent of any negative information, and two-way asymmetrical communication as manipulating publics to accomplish organizational goals (p. 29).

In subsequent research, Grunig (1989) touted the two-way symmetrical model as the most ethical, arguing that its ethical rationale came from the Habermas (1984) ideal speech situation (Grunig \& Grunig, 1992; Pearson 1989). The ideal speech situation emphasizes symmetry and reciprocity, conditions that mirror the twoway symmetrical model (Leeper, 1996). Like Habermas, Grunig defined communication as a process that leads to mutual understanding. "The major purpose of communication is to facilitate understanding among people and such other systems as organizations, publics, or societies," Grunig wrote. "Persuasion of one person by another is less desirable" (Grunig, 1989, p. 38). In 2001, Grunig moderated his views to some extent, contending that the symmetrical model was "inherently ethical," whereas the other models were ethical, "depending on the rules used to ensure ethical practice" (p. 29).

Despite Grunig's (1989) attempts to clarify his views, the model became the target of criticism by scholars. Pieczka (1997) claimed the two-way symmetrical model is utopian, whereas Van der Meiden (1993) argued that such communication is unrealistic for organizations because it requires them to give up goals and objectives vital for survival in the business world. Others said Grunig's model fails to consider how organizations use a combination of the four models in public relations (Leichty \& Springston, 1993). Susskind and Field (1996) noted the difficulty of using the two-way symmetrical model in times of conflict: "In value-laden debates, to compromise or to accommodate neither advances one's self-interest nor increases joint gain" (p. 155).

Cancel, Mitrook, and Cameron (1999) wondered how an organization would deal with morally repugnant publics, especially in situations in which the organization starts from a position based on morally defensible deontological principles. The authors also questioned whether accommodation is logically possible when adapting to one public is done at the expense of another. They proposed a contingency theory of accommodation that attempts to balance intended effects between the client and the public interest. Their 
theory offers a possible alternative to dialogue, but in the end it still emphasizes the importance of dialogue over dissemination.

For others, "dialogue is not a panacea. A dialogic approach cannot force an organization to behave ethically, nor is it even appropriate in some circumstances" (Kent \& Taylor, 2002, p. 24). The term dialogue, Kent and Taylor added, is used ubiquitously and with little specificity. What is understandable is dialogue's appeal to public relations. In a profession beset by criticism for spinning the truth to portray bad news as good and good news as better than it is, public relations embraced dialogue's emphasis on equality, agreement, and mutual benefit. However, Peters's (1999) historical analysis showed that dialogue is not always the balanced, fair approach that it appears to be. Peters argued that "dialogue can be tyrannical and dissemination can be just"(p. 34).

\section{The Debate: Dialogue Versus Dissemination}

In support of his argument, Peters (1999) staged a debate between Socrates, dialogue's greatest proponent, and Jesus, the world's "most enduring voice for dissemination" (p. 35). The Phaedrus, Peters claimed, reflects an anxiety over technology's effects on human interaction. For Socrates, the technology was writing, but it could easily represent the concerns for the dispersion of information across radio, television, and the Internet. Socrates saw true communication as a "matching of minds," a "coupling of desires." In face-to-face speech two people share an event intended for only each other, but "writing allows all manner of strange couplings: the distant influence the near, the dead speak to the living, and the many read what was intended for the few" (Peters, 1999, p. 37).

Peters (1999) described Socrates's vision of communication as a reciprocal love without penetration, a love of wisdom pursued with another human. This is the love of the noble lover who fixes "his attention upon the intelligible and the divine," conceiving "an exalted attitude toward the beloved" (Weaver, 1985, p. 13). In the Phaedrus, Socrates called this type of communication a "blessed life and a life of one mind ... , being masters of themselves and orderly, enslaved in regard to that by which the soul's badness was arising within, freed in regard to that by which virtue was arising" (Plato, 1998, p. 61 [256a-

Journal of Mass Media Ethics, Vol. 21, No. 2-3 (2006): pg. 156-176. DOI. This article is (c) Taylor \& Francis (Routledge) and permission has been granted for this version to appear in e-Publications@Marquette. Taylor \& Francis (Routledge) does not grant permission for this article to be further copied/distributed or hosted elsewhere without the express permission from Taylor \& Francis (Routledge). 
256b]). Genuine love and friendship emerges from this symmetrical relationship. "Socrates treats interpersonal communication as not only a happy mode of message exchange but, at its finest, the mutual salvation of souls in each other's love beneath the blessings of heaven" (Peters, 1999, p. 45). This ideal of communication is "glorious" in its romantic notion of the melding of souls and "severe" in its unrealistic expectations for successful communication (Peters, 1999 , p. 45). Peters echoes concerns of many public relations scholars who believe symmetrical communication is an unattainable normative theory for the practice of public relations.

For Socrates, true love is not dispersed indiscriminately but only shared with a deserving soul who is willing to reciprocate. The effect of this type of communication, whether between lovers in dialogue or the "reciprocal coupling" between speaker and audience in rhetoric, is a "closed communication circuit" (Peters, 1999, p. 46). Instead of promoting the open communication valued by public relations, dialogue emphasizes limited participation in the process and heightened control over the interchange.

Writing may provide more participation and freedom, but its "dispersive properties" allow it to fall into any hands, producing progeny (interpretations) much different than that intended by the message's parent. To expand on the Socratic analogy, the writer's promiscuity could lead to the creation of many illegitimate children who may look like the original but grow to maturity under the influence of strangers. "For Socrates," wrote Peters (1999), "as for many thinkers since, dialogue (fertile coupling) is the norm; dissemination (spilled seed) is the deviation" (p. 49). In writing, as in broadcasting, personal contact is replaced by the illusion of presence. There is no chance for interaction and mutual understanding. The receiver is left to his or her own devices to interpret the soul of the sender.

Socrates's vision of communication, again, is not simply about media - the goodness of speech versus the badness of writingbut about the symmetry and tightness of the relationships in which they are embedded. For Plato's Socrates, the medium is not a mere channel but a whole series of relationships. The critique of writing on papyrus as opposed to writing on souls 
maintains the deeper theme of dialogue: two are needed for love or wisdom. (Peters, 1999, pp. 49-50, italics added).

Socrates wanted mutual discovery, understanding, and agreement, but its reliance on reciprocity threatens to reduce society to quid pro quo relationships. "Social life," Peters (1999) contended, "would be a cycle of payment, rather than gifts" (p. 56). Dialogue also emphasizes selectivity and controlled interpersonal communication, both which can lead to tyranny, seduction, pandering, and missed connections.

As an alternative to dialogue, Peters (1999) offered the synoptic Gospels' celebration of dissemination. In the parable of the sower, Jesus talks about uniformly broadcasting seeds across various types of soil. The harvest is varied depending upon the receptiveness of the receivers. The responsibility for interpreting the message is left to the receiver, who has the autonomy to assign a meaning different from that intended by the sender. Peters suggested that the gap between encoding the message and the audience's decoding of the message "may well be the mark of all forms of communication" (p. 52). The gaps only become obvious with the introduction of a new medium, such as the Internet, which produced outcomes far removed from those intended by its creators.

Contrary to dialogue, the dissemination of the synoptic Gospels values asymmetric relationships and public distribution. The sender ignores individual differences or the possibility of reciprocity. One is expected to treat other people as one would want to be treated regardless of consequences or merit. The father receives the prodigal son with open arms and generosity despite the son's moral and monetary transgressions. Distribution ignores merit and treats all receivers justly and without bias. "There is something both democratic and frightening about such apparent indifference to merit" (Peters, 1999 , p. 54). Furthermore, it is better to give than receive. Instead of imposing obligation, giving blesses the lives of the receivers for their "unprovoked generosity (one-way)" (p. 58). Reciprocity can rob people of individuality and uniqueness, taking away the qualities that form the basis of love. It also can be unjust because it can theoretically limit universal access to communication interactions and processes. permission has been granted for this version to appear in e-Publications@Marquette. Taylor \& Francis (Routledge) does not grant permission for this article to be further copied/distributed or hosted elsewhere without the express permission from Taylor \& Francis (Routledge). 
Clearly there is nothing ethically deficient about broadcasting as a one-way flow. Nor are the gaps between sender and receiver always chasms to be bridged; they are sometimes vistas to be appreciated or distances to be respected. The impossibility of connection, so lamented of late, may be a central and salutary feature of the human lot. The dream of communication has too little respect for personal inaccessibility. (Peters, 1999, p. 59)

The final difference between Socrates and Christ may have the most profound implications for public relations. It also calls into question the very foundation of the argument for two-way symmetrical as being morally superior to one-way dissemination. Platonic love is attracted to beauty. It must be impersonal and general to qualify as love. Socrates sees no value in love of the particular. Christian love, on the other hand, embraces the differences of others, especially those with needs and imperfections. Indeed, one could argue that Christian love exalts diversity, seeing each person as unique and valuable, while Platonic love values the uniting of two souls into a universal oneness that marginalizes individuality. Peters (1999) argued that dissemination as a model for communication better represents the reality of the human agent, unique, different, and imperfect.

"Dissemination is not wreckage; it is our lot" (p. 62).

Dialogue's disgust for the distinct presents public relations with an intriguing paradox. To fulfill Socrates's expectations for dialogue, an organization would select only publics with which it could successfully communicate. Only those most likely to agree with the organization's position would be worthy of love or of a relationship. If the two parties could not reach mutual understanding, the effort would be considered a fruitless waste of energy and love. Thus, for dialogue to truly occur, the organization would select like-minded publics, those judged most likely to reach an agreement with the organization. However, this focus on only those publics possessing the capability to reciprocate and accommodate to the organization's position would directly conflict with the basic assumptions of open systems theory, which calls for adjusting and adapting to changes in the environment (Bivins, 1992). In other words, the demands of dialogue force the organization to become more strategic and selective in its communication and more reliant on homogenous publics to achieve mutual understanding. The use of selective communication designed to persuade like-minded permission has been granted for this version to appear in e-Publications@ Marquette. Taylor \& Francis (Routledge) does not grant permission for this article to be further copied/distributed or hosted elsewhere without the express permission from Taylor \& Francis (Routledge). 
publics transforms dialogue into two-way asymmetric communication, which is based on controlling the environment rather than adjusting and adapting to it. In his critique of writing, Socrates complained that written words reach out to "those who understand as in the same way by those for whom it is in now way fitting...." Without support of the "father" of the words, written words cannot defend against faultfinding and unfair attacks (Plato, 1998, p. 86 [p. 275d-e]; see also Peters, 1999, p. 47). In other words, the sender's motivation for entering into dialogue is not necessarily to hear what the receiver has to say but to make sure the sender's words reach the right people and are understood in the right way.

In early 2005, President George Bush visited cities across the country promoting an overhaul of the social security system. In public meetings, he conversed with "ordinary" people, many of whom were "handpicked to dramatize his points, in front of crowds of supporters" (Kosterlitz, 2005, p. 854). At a town-hall style event in Florida, one of the "regular folks" said he liked the President's plan to allow people to invest Social Security money in the stock market because it would produce higher returns. The President readily agreed with the man's opinion because it was the same as his own. The man turned out to be an activist for a conservative group. At another event aimed at testing public opinion in New Jersey, White House staffers held a dress rehearsal for participants the day before the event. The Democrats also staged town-hall events feature their own activists as "regular folks" (Bailey, Wolffe, \&Lipper, 2005,pp.34-35). These examples show how the burden of reaching understanding and consensus has ultimately led to inequity in the environment and exclusion from the dialogue.

\section{Dialogue and Systems Theory}

The use of systems theory as a foundation for public relations also becomes problematic from the ethical standpoint. Cutlip et al. (2000) defined a system as a set of interdependent units or parts that adjusts and adapts to external (and likely internal) pressures to maintain its goal states (existence). Public relations helps to maintain symmetry between the organization and its publics. With external pressures driving change and adaptation, dialogue's bias toward relationships most likely to lead to agreement becomes even more

Journal of Mass Media Ethics, Vol. 21, No. 2-3 (2006): pg. 156-176. DOI. This article is (c) Taylor \& Francis (Routledge) and permission has been granted for this version to appear in e-Publications@Marquette. Taylor \& Francis (Routledge) does not grant permission for this article to be further copied/distributed or hosted elsewhere without the express permission from Taylor \& Francis (Routledge). 
morally questionable in systems symmetry. In systems theory, stakeholders increase in importance to public relations because of their instrumental value to the organization rather than their intrinsic value as human beings. Bivins (1992) suggested that an organization or system weigh the interests of stakeholders based on their claims on the organization (p. 373). Only those stakeholders considered valuable to the organization's success or possessing the most valid claims might be considered worthy of dialogue, and the dialogue is limited to the extent necessary to bring about agreement and adjustment. An organization could then justify the selective use of dialogue, the strategic selection of publics, and the strategic use communication to reach agreement. This could lead to the creation of a communication caste system for external publics and internal publics. Those employees seen as less instrumental to the success of the organization would then become less worthy of dialogic communication. Bivins (2004) has since modified his position, contending that organizations have the greatest moral obligation to those "linkages" or stakeholders most affected by organizational decisions, particularly those constituents most vulnerable to organizational actions.

Where before ethical decisions were contingent on system inputs (Bivins, 1992, p. 375), now ethical decisions would emphasize system outputs. Individuals are valued as means to achieving corporation ends. Furthermore, the organization's moral obligations arise from factors external to the organization rather than on the moral character of the system itself. The irony of ethical communication based on systems theory and dialogue is that its very emphasis on equality, consensus, and agreement could promote inequity in the selection of publics (even those considered most vulnerable), a false consensus arising from the selection criteria, and disparate treatment of publics based on their instrumental or even noninstrumental value to the organization.

These ironies also are present the two-way symmetrical model. Grunig and Hunt (1984) contended that two-way symmetrical communication would make organizations more responsible to their publics. However, theoretically, the two-way symmetrical model reduces the responsibility of the organization and the public in determining right action. The very act of negotiating right relieves each party of some of its responsibility to be right. One's morals permission has been granted for this version to appear in e-Publications@Marquette. Taylor \& Francis (Routledge) does not grant permission for this article to be further copied/distributed or hosted elsewhere without the express permission from Taylor \& Francis (Routledge). 
become fluid, flowing through channels offering the least resistance or the most opportunity. Symmetry means that an organization or public can shift part of the responsibility for determining right action to the other party. Thus, instead of increasing an organization's burden for right action, symmetry may reduce expectations and encourage adapting for the sake of reaching an agreement acceptable to both parties. Cancel et al. (1999) noted that taking a moral stand on some issues may demand placing principle above process in communicating. They argued that practitioners shift between advocacy and accommodation depending upon a variety of variables, such as corporate culture, size of the organization, individual characteristics, and public relations access to the dominant coalition. However, this contingency approach, like symmetry, also smacks of ethical relativism. Instead of abdicating moral responsibility to reach an external agreement, the practitioner adjusts moral behaviors to fit external conditions or variables. One might make moral stands but only if the conditions call for them.

Dialogue also requires equality among parties and the sharing of information. However, even the most sincere corporation might find it difficult to create a situation of equality in communicating with its various stakeholders. The corporation employs professional communicators valued for expertise far superior to that possessed by civic groups, smaller organizations, and even the government. Activist groups often lack the funding necessary to match wits with corporate public relations personnel. Equality also becomes a factor in considering the sharing of information. In theory, one would be completely open in dialogic relationships, reciprocating with each communicative action, and eventually having all information in common. However, most organizations have access to far greater resources in information and technology, giving them an advantage in the relationship. If the goal of the discourse is agreement, either party might hold back information that might discourage consensus or might use its resources to supply information that encourage consensus. The outcome would be a false consensus reached through covert deception or overt coercion. When the U.S. Department of Education paid syndicated columnist and TV personality Armstrong Williams to promote the No Child Left Behind Act, it used its financial resources to guarantee that Armstrong understood and agreed with the message. permission has been granted for this version to appear in e-Publications@ Marquette. Taylor \& Francis (Routledge) does not grant permission for this article to be further copied/distributed or hosted elsewhere without the express permission from Taylor \& Francis (Routledge). 
He reciprocated by repeating the message as if it were his own opinion (Friel, 2005). Truth was negotiated, and symmetry was achieved.

Dialogue also threatens to become a paternalistic approach to communication. The elite father serves as a mentor to a noble disciple carefully selected for his beauty and receptive spirit. An organization could selectively choose only those stakeholders who could reciprocate through an economic and emotional attachment. Dialogue could easily degenerate to a quid pro quo relationship with those whose gifts would best benefit the bottom line. This would mean entering into dialogue with people with the means to give something back. This type of relationship places a high priority on strategic selection, strategic communication, and strategic adaptation. Thus, the very antitheses of dialogue-persuasive and strategic communication-could become a natural outgrowth of the dialogic relationship. To resolve this conflict, a necessary step is to shift the moral emphasis of public relations from establishing relationships to adopting universal community principles (Arnett, 1986, p. 97). Common principles and values should precede and take precedence over relationships.

These are admittedly extreme cases. Plenty of anecdotal evidence exists in the public relations literature to support the benefits of two-way symmetrical communication. While still advocating the two-way symmetrical model as the most effective for public relations, Grunig and Grunig (1992) noted calls for a continuum between twoway asymmetrical and symmetrical communication and agreed that professional practice encompasses aspects of both models. However, they again questioned the moral validity of dissemination models of public relations, categorizing them under the umbrella of craft public relations. The problem with this kind of dichotomy is that it fails to consider the possibility of two parties reconciling their differences without resorting to persuasion or dialogue. Indeed, the gaps between two parties may serve as the foundation for professional relationships in which distance protects against personal and public deception.

Take for instance, the proverbial relationship between public relations practitioners and journalists. Journalists often rely on public relations practitioners for newsworthy information and sources. Public relations practitioners count on journalists for media coverage and third party endorsements. The two have complementary but distinct permission has been granted for this version to appear in e-Publications@Marquette. Taylor \& Francis (Routledge) does not grant permission for this article to be further copied/distributed or hosted elsewhere without the express permission from Taylor \& Francis (Routledge). 
objectives. However, the recognition of these differences allows each party to determine its interdependence with the other without turning to manipulation. Ironically, the potential for manipulation (or corrupting media channels) increases in a dialogic relationship based on reciprocity and mutual benefit. Public relations practitioners would offer journalists first dibs on a big story in return for favorable treatment and good play on the story. At the other end of a continuum between dialogue and dissemination, journalists would make editorial decisions about a disseminated press release or pitch solely on the merits of its news content and value to the publication's readers.

In excluding dissent in favor of agreeable supporters, President Bush's efforts to reform Social Security may have violated the differences, the gaps expected to exist between the government and the governed. A majority of the public may not have embraced his reforms because his campaign focused on managed agreement rather than reconciled differences. In contrast, dissemination allows for publics to decide how they want to manage their own relationships with the organization. Just because a company disseminates information without any framework or expectation of public response does not mean that the company will ignore responses. Absence of immediate feedback puts more responsibility on the organization to communicate accurately and effectively in the first place. Peters (1999) argued that a "receiver-oriented model in which the sender has no control over the harvest" ( $p .35$ ) demands that messages be as clear as possible so meaning is not lost in the interpretation. "It becomes the hearer's responsibility to close the loop without the aid of the speaker" (Peters, 1999, p. 52). A company committed to character and community does not wait for a public response to correct inconsistencies in its communication and behavior. This does not mean that agreement and feedback are not important; it means that it should not be the ultimate concern. Of greater concern is one's regard for self, the other person, and community.

The act of becoming communities implies a process in which community members engage in an ongoing process of interpretation (Royce, 1988; Trotter, 2001), not necessarily dialogue. Community members can interpret public reaction because they share the values and loyalties of the community. One's interpretations of those values and loyalties might be different, but having care and concern for permission has been granted for this version to appear in e-Publications@Marquette. Taylor \& Francis (Routledge) does not grant permission for this article to be further copied/distributed or hosted elsewhere without the express permission from Taylor \& Francis (Routledge). 
community members engenders empathy, an emotional understanding. Companies hire public relations people because they speak a different language than that normally spoken in the business community. Public relations people tend to be more in tune with the press and the public. They intuitively know when corporate behavior will spark negative or positive reactions in the court of public opinion. Their role is not so much to reach an agreement with the disparate publics but to act as an interpreter between the organization's dominant coalition and the people affected by an organization. If the organization exploits or undermines the community by violating community values and norms, no amount of dialogue or two-way communication will bridge the chasm.

Communities emerge from a combination of dialogue, dissemination, and interpretation. The goal of public relations is not to promote consensus in a community or even understanding. The goal of public relations is to identify the distinctive aspects of the community and understand and appreciate its community values that make it unique. Kruckeberg and Starck (1988) contended that the goal of community relations in public relations is to "restore and maintain a sense of community, which has been lost in contemporary society" ( $p$. 26). American idealist Josiah Royce (1908) attributed the loss of community to the leveling effect of industrialization. By leveling effect, Royce meant the loss of identity, either as individuals or as communities. In modern times, the leveling effect has resulted from the mainstreaming of culture through the mass media, mass marketing, and mass technologies. People have lost their sense of place, family, past, and future. Trotter (2001) explained that Royce's communities consisted of common "memories and expectations," and community members cooperate in seeking truth. "In the highest stages of moral life," Trotter continued, "individuals develop, through empathy and other powers of social communication, a deeper moral insight and an ability to interpret the ideals of ever wider cross sections of humanity" (pp. 83-84). As members of a community, individuals interpret their own goals and ideals "in terms of an overarching loyalty to humanity" (p. 84).

Royce's community of inquiry views communication in much the same way as the philosopher G. W. F. Hegel, who, according to Peters (1999), saw communication not as shared information but "as the permission has been granted for this version to appear in e-Publications@Marquette. Taylor \& Francis (Routledge) does not grant permission for this article to be further copied/distributed or hosted elsewhere without the express permission from Taylor \& Francis (Routledge). 
process whereby a free human world is built collectively" (p. 110). According to Peters, Hegel would not have separated the message from the channel because communication is embodied in a person's subjective interior and in external objects. One gains knowledge of the world as one comes to understand how particulars make up the whole. In other words, the building of communities and relationships is a product of reconciling the mutual recognition of others' differences, not only in what they say but how they say it. Hegel (1948) said, "Life is the union of union and nonunion" (p. 312). "Hence 'communication' will always be more than the shuttling of mind-stuff. It is the founding of a world" (as cited in Peters, 1999, p. 112; see Hegel, 1948). It also is the stuff out of which relationships develop. Human existence depends on the recognition of another human being. Public relations recognizes that activist groups may disagree, employees may not feel secure in their jobs, neighbors may not want a new plant in their backyard, and customers may need reassurance that one's products are safe. By embracing diversity in opinion, public relations actually becomes a more human enterprise. "Recognition enables humanity. Self-consciousness exists only as it is recognized" (as cited in Peters, 1999, p. 115; see Hegel, 1977).

Recognition involves interpretation. Communication becomes the process of interpreting one's world and then reconciling the subjective recognitions with objective meanings and visa versa. Thus, meanings are both private and public phenomena The communication intended by a public relations practitioner may only be partially recognized in a news story written by a journalist. The practitioner cannot physically express his or her intentions to the reader, but the reader sees hints of the practitioner's intentions in the media story. The multiplicity of interactions between an organization and its stakeholders makes it impossible to control all possible interpretations and outcomes. Peters (1999) contended that this interaction is a model of communication in general. "To live is to leave traces. To speak to another is to produce signs that are independent of one's soul and are interpreted without one's control" (p. 118).

Thus, an organization's relationships with its publics are not understood through the fusing of one person with another (such as management and stakeholders) but through the establishing of "conditions under which the mutual recognition of self-conscious permission has been granted for this version to appear in e-Publications@ Marquette. Taylor \& Francis (Routledge) does not grant permission for this article to be further copied/distributed or hosted elsewhere without the express permission from Taylor \& Francis (Routledge). 
individuals is possible" (p. 112). This kind of recognition occurs when the local bank sponsors an evening budgeting class for newlyweds, a bike manufacturer trains a local Boy Scout troop to assemble and service their own bikes, and a newspaper sponsors the community spelling bee.

\section{Recognition Leads to Reconciliation}

In a sense, people must overcome differences while at the same time appreciating the differences in others. Society emerges and changes from this recognition and reconciliation. It is also possible that this is at the heart of relationships. The public relations practitioner recognizes the individuality of a particular public and then reconciles, not eliminates, those differences in building a relationship. Journalists may never feel comfortable about working with a public relations practitioners, but the recognition of their differences leads to the reconciliation necessary for them to accomplish their disparate goals.

Communication breakdowns are as likely to reveal truth as they are to suppress it. For public relations this means more might be learned about a situation by focusing on the problems inhibiting communication rather than on the express goal of the communication. All out efforts to reach agreement may lead both parties to suppress differences rather than recognizing them and reconciling them. This process exposes a paradox in dialogic communication. The very goal of agreement and consensus may well cause the parties to overlook and suppress issues critical to any kind of long-term agreement or reconciliation. To reach agreement, the two parties might minimize differences that smolder in the background until circumstances or social conditions push them to the forefront, forcing the parties back to the negotiating table to find another artificial agreement to mask the underlying non-agreement.

Kierkegaard saw communication as "strategic misunderstanding" (Peters, 1999, p. 129). The responsibility for interpreting the communication is left to the hearers. The message is cloaked in irony; it cannot be separated from the mode of communication. In his writings, Kierkegaard "employed indirect communication ... in order to take himself as author out of the picture and to leave the reader alone with the ideas" (Hong \& Hong, 1983, p. permission has been granted for this version to appear in e-Publications@Marquette. Taylor \& Francis (Routledge) does not grant permission for this article to be further copied/distributed or hosted elsewhere without the express permission from Taylor \& Francis (Routledge). 
$x)$. As with Jesus's parables, Kierkegaard's idea of communication is to pass along messages not readily apparent to everyone but blatantly obvious to those in the know. In an age of technology, distance, and speed, dialogue's ideal mode of communication, face-to-face, is a rare commodity, and the hearer's ability to test Habermas's (1996) validity claims - truth, rightness, and truthfulness - is nearly impossible ( $p$. 137). Communication is difficult, and failure to achieve understanding or agreement does not mean that communication did not take place. Indeed, problems in communication may tell more about individuals and others than the absence of a communication breakdown. In relations with others, the particular takes precedence over the general. Others are valued for their uniqueness, their differences. As we begin to reconcile those differences, we develop relationships based on love of the individual and individuality not the possibility of cloning that person into a common mindset. The emphasis is not on making the person a part of a crowd but identifying the persons in the crowd as individuals pursuing a variety of goals and ideals. The purpose of communication then becomes an effort to not only learn more about others but to gain a greater understanding of who we are.

Organizations, like other community members, should cherish the chance to distinguish differences because those very differences clarify our mission and principles to internal and external audiences. As Mill (1863/2002) wrote, "He who knows only his side of the case, knows little of that" (p. 38). Mill contended that hearing another's arguments through intermediaries is not sufficient. One must hear from the people possessing those arguments and willing to passionately defend them. Unless placed into "the mental position of those who think differently," people "cannot know themselves the doctrine which they themselves profess" (p. 38). Public relations becomes the corporate conscience, not because they know the organization better than anybody else, but because they know better than anybody else in the organization what outsiders think.

Thus the goal of public relations changes from finding agreement to discovering differences. As differences become transparent, even those differences between who we think we are and who others perceive us to be, they can be reconciled in a way that places a high value on our common humanity. Using this framework, we engage people or publics in communication, not in an effort to change them or even to change us, but because as human beings, we

Journal of Mass Media Ethics, Vol. 21, No. 2-3 (2006): pg. 156-176. DOI. This article is (c) Taylor \& Francis (Routledge) and permission has been granted for this version to appear in e-Publications@Marquette. Taylor \& Francis (Routledge) does not grant permission for this article to be further copied/distributed or hosted elsewhere without the express permission from Taylor \& Francis (Routledge). 
value our relationships with other human beings. The outcome of this type of relationship is a different kind of change, one not of adaptation or adjustment in response to outside pressures, but constitutional change in who we are and how we perceive ourselves-which then leads to changes in the way we interact and communicate. Our external publics are empowered to change themselves based on internal values and loyalties rather than outside coercion or obligatory reciprocity.

This new approach to public relations emphasizes reconciliation through dissemination and engagement. The goal of communication is to achieve authenticity or what Kierkegaard calls a "persistent striving" for truth, a striving to become a person who acts without deception (Kierkegaard, 1971, p. 110, 119-122). The authentic person sacrifices his or her will to universal moral laws while "constantly striving" to fulfill moral ideals (Copleston, 1985, p. 348; see also Kierkegaard, 1971). The authentic organization would not settle for an artificial agreement or a balance between opposing opinions, but seek to find the truth in opposition and agreement. If the organization harbors more error than truth, it will feel obligated to rewrite its moral constitution. Change is internally motivated. Public relations will value diversity, uniqueness, and pluralism. It will look at stakeholders as individual human beings, not inhuman publics. It will value equity in action and purpose over maintaining the equilibrium of the system. Organizations will achieve authority through their appeal to universal values and loyalties.

Harvard philosopher Carl Friedrich (1963) provided a model for this new type of public relations in his description of a constitutional order. The order consists of people with common interests and beliefs founded on basic universal principles. The common people have freedom to act and think for themselves, but their commitment to basic principles ties them together in the common interests of the order. Dissent, or might one say difference, is essential because the "continuous struggle in the marketplace of ideas" helps to maintain the authority of the order or organization. It is critical for the organization to continually engage its members through communication. As organizational members participate in this discourse, they begin to look upon these communications as their own, "as something they have taken hold of as much as it has taken hold of them" (pp. 53-54). permission has been granted for this version to appear in e-Publications@Marquette. Taylor \& Francis (Routledge) does not grant permission for this article to be further copied/distributed or hosted elsewhere without the express permission from Taylor \& Francis (Routledge). 
As the two parties exchange communication, the organization uses its authority to augment and implement the actions of the stakeholders affected by that authority. As these stakeholders begin to see the organization as a partner in achieving their own goals as well as community goals, they become engaged. They do not reach a consensus on plans of action so much as they participate in a common cause based on universal principles or those principles to which all people might be loyal (see Royce, 1908). They then develop a loyalty of a different type, one based on common values, not reciprocation. Communication breakdowns are valued because they expose differences in how the parties interpret these values. Ultimately, relationships are based on internalized commonalities rather than externalized expectations and agreement.

Corporations also are tenants of the people. They receive special privileges in society by virtue of legislation approved by bodies elected by the very people on whom the organizations depend for their survival. Corporations should encourage discussion and debate because they recognize, as every other human endeavor recognizes, that they are not infallible. Like individuals, organizations are "capable of rectifying mistakes, by discussion and experience" (Mill, 2002, p. 22). Corporations do not communicate with various groups to achieve agreement. They communicate because they have something worth saying, and they recognize that supporters and dissidents have something worth saying, even if it is easily exposed as error. In other words, organizations are open to opposing ideas because they are part of a community of inquiry and care about other members of that community. The organization's purpose is finding truth, not achieving what may be an artificial agreement.

It would be wrong to say that agreement is not desirable, but a more realistic approach would be to seek agreement on general principles. This allows for reasonable discussion and discourse between disparate parties. John Rawls (1993) saw this ability to recognize the value of differences among perceptions while sharing common beliefs about justice in a free society as reasonable pluralism. "Once we accept the fact that reasonable pluralism is a permanent condition of public culture under free institutions, the idea of the reasonable is more suitable as part of the basis of public justification" (Rawls, 1993, p. 129, as cited in McCarthy, 1994, p. 60). Without a recognition of permission has been granted for this version to appear in e-Publications@Marquette. Taylor \& Francis (Routledge) does not grant permission for this article to be further copied/distributed or hosted elsewhere without the express permission from Taylor \& Francis (Routledge). 
reasonable pluralism and a willingness to have one's ideas widely dispersed, powerful organizations may begin to "impose their beliefs because, they say, their beliefs are true, and not because they are their beliefs" (Rawls, 1993, p. 61; see also McCarthy, 1994, p. 60). When people make the claim of truth based on their own beliefs and then try to impose those beliefs on others, people are viewed as unreasonable by an open society. Thus, reasonable citizens do not impose their will on others but reconcile their beliefs with those of others.

Organizations do not necessarily need to use symmetrical communication to achieve a relationship with their stakeholders. They recognize a plurality of beliefs and disseminate information as to their beliefs, recognizing that others, even a minority, may differ. "If the opinion is right, they are deprived of the opportunity of exchanging error for truth: if wrong, they lose, what is almost as great a benefit, the clearer perception and livelier impression of truth, produced by its collision with error," wrote Mill (2002, p. 19). With a greater focus on identifying differences, public relations acts to reconcile disparate opinions and facilitate the discovery of truth inside and outside the organization. Suppressing an opposing opinion that contains truth may cause the organization to hold opinions laced with prejudice and error that lead it further and further away from the truth. Ultimately the time will come in which "favorable circumstances" (p. 30) allow for the truth to be known, and the people, "whose whole mental development is cramped," react with anger against the source of their deception (pp. 34-35). Public relations should focus more on organizational character and the discovery and dissemination of truth than it does on dialogue. The field will find that by giving up some control over the conversation, it will gain a greater voice in the conversation. The public will begin to see practitioners as partners in the search for truth, not as parents meddling in the meanings of their message offspring.

\section{Conclusions}

In this article, we show that public relations' infatuation with dialogue may create unrealistic expectations for organizational and individual communication. Indeed, adherence to dialogic approaches, such as the twoway symmetrical model, though well intended, may actually cause public relations to slip into simple quid pro quo

Journal of Mass Media Ethics, Vol. 21, No. 2-3 (2006): pg. 156-176. DOI. This article is (c) Taylor \& Francis (Routledge) and permission has been granted for this version to appear in e-Publications@Marquette. Taylor \& Francis (Routledge) does not grant permission for this article to be further copied/distributed or hosted elsewhere without the express permission from Taylor \& Francis (Routledge). 
relationships. Peters's (1999) analysis of communication approaches advocated by Socrates and Jesus exposed the flaws of looking at twoway communication as most ethical and dissemination as the most unethical. Dissemination can be just and dialogue unjust. More important than the mode of communication is the morality of communicators and their willingness to recognize and reconcile differences. Finding truth becomes much more important than achieving agreement, and change is motivated by a commitment to character rather than a desire to manage reputation and consensus.

The goals of symmetrical communication or dialogic communication are commendable but unreasonable. The common ground sought by competing parties is not as important as the common principles of truth, freedom, liberty, and human rights that both espouse. Organizations should engage in communication because they recognize the sovereignty of the individual, value liberty, and seek truth. They disseminate ideas as a matter of conscience and listen to public response as a matter of principle.

\section{References}

1. Arnett, R. C. (1986). Communication and community: Implications of Martin Buber's dialogue. Carbondale: Southern Illinois University Press.

2. Bailey, H., Wolffe, R., \& Lipper, T. (2005, March 14). Tricks of the trade. Newsweek, pp. 34-35. Retrieved January 18, 2006, from http://proquest.umi.com

3. Bivins, T. H. (1992). A systems model for ethical decision making in public relations. Journal of Business Ethics, 18, 365-383.

4. Bivins, T. H. (2004). Mixed media: Moral distinctions in advertising, public relations and journalism. Mahwah, NJ: Lawrence Erlbaum Associates, Inc.

5. Cancel, A. E., Mitrook, M. A., \& Cameron, G. T. (1999). Testing the contingency theory of accommodation in public relations. Public Relations Review, 25, 171-197.

6. Communicating corporate change requires strong internal campaign. (2001, June 25). PR News. Retrieved from wysiwyg://14/http://proquest.umi.com

Journal of Mass Media Ethics, Vol. 21, No. 2-3 (2006): pg. 156-176. DOI. This article is (c) Taylor \& Francis (Routledge) and permission has been granted for this version to appear in e-Publications@ Marquette. Taylor \& Francis (Routledge) does not grant permission for this article to be further copied/distributed or hosted elsewhere without the express permission from Taylor \& Francis (Routledge). 
NOT THE PUBLISHED VERSION; this is the author's final, peer-reviewed manuscript. The published version may be accessed by following the link in the citation at the bottom of the page.

7. Copleston, F. (1985). A history of philosophy: Volume 7: Fichte to Nietzsche. New York: Image.

8. Cutlip, S. M., Center, A. H., \& Broom, G. M. (2000). Effective public relations (8th ed.). Englewood Cliffs, NJ: Prentice Hall.

9. Friedrich, C. J. (1963). Loyalty and authority. In H. M. Ruitenbeek (Ed.), The dilemma of organizational society (pp. 49-58). New York: Dutton.

10. Friel, B. (2005, July 1). Chain reaction. Government Executive, 37, 64. Retrieved January 18, 2006, from http.//proquest.umi.com

11. Grunig, J. E. (1989). Symmetrical presuppositions as a framework for public relations theory. In C. Botan \& V. Hazelton (Eds.), Public relations theory (pp. 17-44). Hillsdale, NJ: Lawrence Erlbaum Associates, Inc.

12. Grunig, J. E., \& Grunig, L. (1992). Models of public relations and communication. In

13. J. E. Grunig (Ed.), Excellence in public relations and communication management (pp. 285-325). Hillsdale, NJ: Lawrence Erlbaum Associates, Inc.

14. Grunig, J. E., \& Hunt, T. (1984) Managing public relations. New York: Holt, Rinehart and Winston.

15. Habermas, J. (1984). The theory of communicative action (Vol. 1, T. McCarthy, Trans.). Boston: Beacon.

16. Habermas, J. (1996). Moral consciousness and communicative action (C. Lenhardt \& S. Weber, Trans.). Cambridge, MA: MIT Press.

17. Hegel, G. W. F. (1948). Early theological writings (T. M. Knox, Trans.). Chicago: University of Chicago Press.

18. Hegel, G. W. F. (1977). Phenomenology of spirit (A. V. Miller, Trans.). New York: Oxford University Press.

19. Hong, H. V., \& Hong E. H. (1983). Introduction. In S. Kierkegaard (Ed.), Fear and trembling. Repetition (H. V. Hong \& E. H. Hong Trans.) Princeton, NJ: Princeton University Press.

Journal of Mass Media Ethics, Vol. 21, No. 2-3 (2006): pg. 156-176. DOI. This article is @ Taylor \& Francis (Routledge) and permission has been granted for this version to appear in e-Publications@Marquette. Taylor \& Francis (Routledge) does not grant permission for this article to be further copied/distributed or hosted elsewhere without the express permission from Taylor \& Francis (Routledge). 
20. James, W. (1952). The principles of psychology. In R. Hutchins (Ed.), Great books of the western world, vol. 53. Chicago: Encyclopedia Britannica. (Original work published 1890)

21. Kent, M. L., \& Taylor, M. (2002). Toward a dialogic theory of public relations. Public Relations Review, 28, 21-37.

22. Kierkegaard, S. (1971). Concluding unscientific postscript (D. F. Swenson \& W. Lowrie, Trans.) Princeton, NJ: Princeton University Press.

23. Kosterlitz, J. (2005, March 19). In search of Plan B. National Journal, 854. Retrieved from http://proquest.umi.com

24. Kruckeberg, D. \& Starck, K. (1988). Public relations and community: $A$ reconstructed theory. New York: Praeger.

25. Leeper, R. V. (1996). Moral objectivity, Jurgen Habermas's discourse ethics, and public relations. Public Relations Review 22, 133-150.

26. Leichty, G., \& Springston, J. (1993). Reconsidering public relations models. Public Relations Review, 19, 327-339.

27. McCarthy, T. (1994). Kantian constructivism and reconstructivism: Rawls and Habermas in dialogue. Ethics, 1, 44-63.

28. Mill, J. S. (2002). On liberty, In The basic writings of John Stuart Mill. New York: Modern Library. (Original work published 1863)

29. Pearson, R. (1989). Business ethics as communication ethics: Public relations practice and the idea of dialogue. In C. Botan \& V. Hazelton (Eds.), Public relations theory (pp. 111-134). Hillsdale, NJ: Lawrence Erlbaum Associates.

30. Peters, J. D. (1999). Speaking into the air: A history of the idea of communication. Chicago: University of Chicago Press.

31. Pieczka, M. (1997). Understanding in public relations. Australian Journal of Communication, 24(2), 65-79.

32. Plato. (1998). Phaedrus (J. H. Nichols, Trans.) Ithaca, NY: Cornell University Press.

33. Rawls, J. (1993). Political liberalism. New York: Columbia University Press.

Journal of Mass Media Ethics, Vol. 21, No. 2-3 (2006): pg. 156-176. DOI. This article is (c) Taylor \& Francis (Routledge) and permission has been granted for this version to appear in e-Publications@Marquette. Taylor \& Francis (Routledge) does not grant permission for this article to be further copied/distributed or hosted elsewhere without the express permission from Taylor \& Francis (Routledge). 
NOT THE PUBLISHED VERSION; this is the author's final, peer-reviewed manuscript. The published version may be accessed by following the link in the citation at the bottom of the page.

34. Royce, J. (1908). The philosophy of loyalty. New York: MacMillan.

35. Susskind, L., \& Field, P. (1996). Dealing with an angry public: The mutual gains approach to resolving disputes. New York: Free Press.

36. Royce, J. (1988). The problem of Christianity. In J. E. Smith \& W. Kluback (Eds.), Josiah Royce (pp. 217-338). Mahwah, NJ: Paulist.

37. Trotter, G. (2001). On Royce. Belmont, CA: Wadsworth.

38. Weaver, R. M. (1985). The ethics of rhetoric. Mahwah, NJ: Hermagoras.

39. Van der Meiden, A. (1993). Public relations and "other" modalities of professional communication: Asymmetric presuppositions for a new theoretical discussion. International Public Relations Review, 16(3), 811.

Journal of Mass Media Ethics, Vol. 21, No. 2-3 (2006): pg. 156-176. DOI. This article is @ Taylor \& Francis (Routledge) and permission has been granted for this version to appear in e-Publications@ Marquette. Taylor \& Francis (Routledge) does not grant permission for this article to be further copied/distributed or hosted elsewhere without the express permission from Taylor \& Francis (Routledge). 